\title{
Sentrale begreper relatert til fysisk aktivitet: Forslag til bruk og forståelse
}

\author{
Kjersti Andersen Nerhus ${ }^{1}$, Sigmund A. Anderssen ${ }^{2,3}$, Hans Erik Lerkelund ${ }^{4}$ og Elin Kolle ${ }^{2}$ \\ 1) Nasjonalt folkehelseinstitutt, Divisjon for epidemiologi, Postboks 4404 Nydalen, 0403 Oslo \\ 2) Norges idrettshøgskole, Seksjon for idrettsmedisinske fag, Postboks 4014 Ullevål Stadion, 0806 Oslo \\ 3) Nasjonalt fagråd for fysisk aktivitet, Postboks 7000, St. Olavs plass, 0130 Oslo \\ 4) Friluftslivets fellesorganisasjon, Nedre Slottsgate 25, 0157 Oslo
}

Korrespondanse: Kjersti Andersen NerhusＥ-post: kjersti.andersen.nerhus@fhi.noＴelefon: 21078164

\begin{abstract}
SAMMENDRAG
Innen fagområdet fysisk aktivitet eksisterer det en rekke sentrale begreper som har vist seg å ofte bli forvekslet med hverandre eller bli brukt synonymt selv om de har ulik betydning. Fysisk aktivitet og trening er eksempler på to begrep som i mange sammenhenger brukes om hverandre. Målet med denne artikkelen er å gi en oversikt over vanlig brukte begreper som er relatert til fysisk aktivitet og foreslå en avgrensning for å tydeliggiøre betydningen av og innholdet i hvert enkelt begrep. Femten begrep ble inkludert i artikkelen, og disse ble identifisert med utgangspunkt $\mathrm{i}$ både faglitteratur, offentlige publikasjoner, media og ulike typer undersøkelser. Søk i både norsk og engelsk litteratur og innspill fra personer innen offentlig forvaltning og aktuelle fagmiljø i Norge ble benyttet for å komme frem til begrepsforklaringene. De foreslåtte forklaringene er ment som anbefalinger i forhold til bruk og forståelse. Det lar seg ikke gjøre å presentere noen form for fasit som omfatter alle nyanser av et begrep tilpasset alle formål. Målet er likevel at de foreslåtte begrepene med tilhørende forklaringer skal kunne benyttes på tvers av ulike fagfelt, organisasjoner og studier slik at det blir en enhetlig forståelse av hva som menes når et bestemt begrep benyttes.
\end{abstract}

\section{BAKGRUNN}

Det er godt dokumentert at regelmessig fysisk aktivitet er viktig for en sunn livsstil. Generelt brukes begreper knyttet til fysisk aktivitet ofte og i mange ulike sammenhenger. Eksempler på slike begrep er fysisk form, trening, mosjon og friluftsliv. I forskningssammenheng, rådgivning, media og lignende viser det seg at noen begrep ofte forveksles med hverandre eller brukes synonymt selv om de har ulik betydning. Dette kan føre til forvirring $\mathrm{i}$ forhold til hva som faktisk menes når de ulike begrepene benyttes, og det at blant annet fysisk aktivitet defineres forskjellig i ulike studier gjør det vanskelig å sammenligne resultater mellom ulike studier. Det er derfor viktig med en felles forståelse av de ulike begrepene, slik at man unngår misforståelser eller at beslutninger tas på feil grunnlag.

Som en del av oppfølgingen av Handlingsplan for fysisk aktivitet (2005-2009) - Sammen for fysisk aktivitet (1) ble det nedsatt en tverrfaglig arbeidsgruppe som blant annet skulle identifisere og komme med forslag til klargjøring av begreper relatert til fysisk aktivitet. Helsedirektoratet var ansvarlig for å koordinere arbeidsgruppen som representerte ulike råd, offentlige institusjoner og organisasjoner i Norge (Friluftslivets fellesorganisasjon (på vegne av Direktoratet for naturforvaltning), Helsedirektoratet, Nasjonalt folkehelseinstitutt, Nasjonalt råd for fysisk aktivitet, Statistisk sentralbyrå og Transportøkonomisk institutt).

Hensikten med denne artikkelen er å gi en oversikt over vanlig brukte begreper som er relatert til fysisk aktivitet og komme med forslag til hvordan disse begrepene kan og bør forklares uavhengig av fagfelt.

\section{Metode}

Identifisering av hvilke begreper som skulle forklares ble gjort ved å ta utgangspunkt i begreper som er mye benyttet både i faglitteratur, offentlige publikasjoner, media og ulike typer undersøkelser. Ut i fra dette diskuterte arbeidsgruppen seg frem til hvilke begreper som ble ansett for å være mest relevante, og det ble gjort en avgrensning som omfattet følgende 15 begreper: Fysisk aktivitet, fysisk inaktivitet, intensitetsnivå, fysisk form, trening, mosjon, trim, utholdenhet, idrett, sport, hverdagsaktivitet, lavterskelaktivitet, friluftsliv, kroppsøving og fysisk aktivitet i skolen.

Ulike fremgangsmåter ble brukt for å komme frem til forslag til avklaringer av de ulike begrepene. For alle begrepene ble det gjort søk i både norsk og engelsk litteratur. Søkebaser som ble brukt var PubMed, ISI Web of Science samt norske databaser. Der det var vanskelig å finne klare definisjoner i litteraturen kontaktet vi personer innen offentlig forvaltning og aktuelle fagmiljø i Norge, og innspill fra disse ble brukt som utgangspunkt for forslag til definisjoner. Begrepsavklaringene i denne artikkelen er dermed basert på enten 1) kun eksisterende litteratur (begrepene fysisk aktivitet, fysisk inaktivitet, intensitetsnivå, fysisk form, trening, utholdenhet), 2) både eksisterende litteratur og innspill fra relevante personer (begrepene mosjon, trim, idrett, sport, friluftsliv, kroppsøving og fysisk aktivitet i skolen) eller 3) utelukkende på innspill og diskusjon med relevante personer (begrepene hverdagsaktivitet og lavterskelaktivitet). I det følgende presenteres begrepene i rekkefølge etter hvilket kunnskapsgrunnlag begrepene er basert på. 


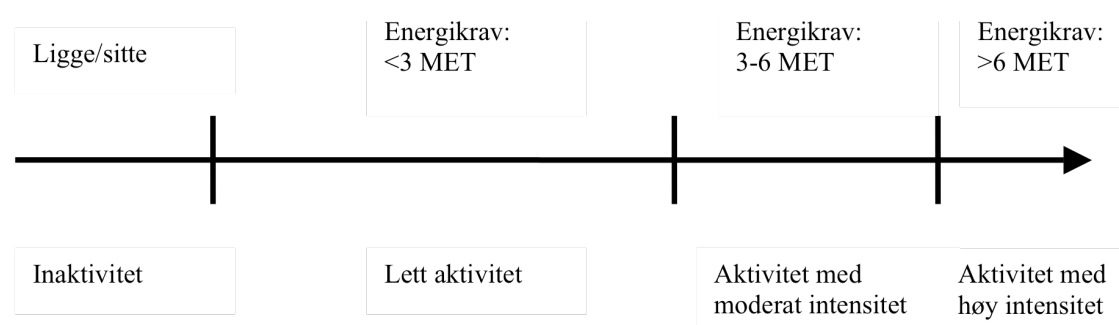

Figur 1. Kontinuum av fysisk aktivitet og intensitetsnivå.

\section{AVKLARING AV BEGREPER}

\section{1) Avklaringer basert på eksisterende litteratur}

\section{Fysisk aktivitet}

Fysisk aktivitet kan defineres som enhver kroppslig bevegelse initiert av skjelettmuskulatur som resulterer i en økning i energiforbruket utover hvilenivå. Energiforbruk relatert til fysisk aktivitet er den mest variable komponenten av en persons daglige energiforbruk $(2,3)$. Fysisk aktivitet består av ulike dimensjoner $(2,4,5)$ :

1. Intensitet. Måles som absolutt intensitet (energiforbruk per tidsenhet) eller som relativ intensitet (andel av maksimal kapasitet). Intensiteten deles ofte opp i lav, moderat og høy.

2. Frekvens: Antall ganger med aktivitet i løpet av en gitt tidsperiode (for eksempel antall ganger per uke eller måned).

3. Varighet: Tid brukt på fysisk aktivitet (for eksempel minutter eller timer).

Intensitet, frekvens og varighet av aktiviteten utgjør total mengde (volum) fysisk aktivitet og dette utgjør energiforbruket ved fysisk aktivitet (6).

Andre viktige dimensjoner av fysisk aktivitet er type aktivitet (for eksempel sykling, løping, turgåing, ballspill, dans, hagearbeid) og hensikt med aktiviteten (konteksten aktiviteten utøves i).

\section{Fysisk inaktivitet}

Fysisk inaktivitet kan forklares som en tilstand hvor det er minimal økning i energiforbruket utover hvilenivå. I praksis vil det si å ligge eller å sitte i ro i våken tilstand. Personer som beveger seg lite både i arbeid og i fritid, som sitter eller ligger mye og som i stor grad benytter seg av motoriserte transport- og hjelpemidler kan karakteriseres som fysisk inaktive $(6,7)$.

\section{Intensitetsnivå}

Intensitetsnivået for fysisk aktivitet kan måles gjennom mengde brukt energi, og det er vanlig å uttrykke forbruket som et multiplum av energiforbruket i hvile (hvilestoffskiftet). Forholdet mellom energiforbruket under fysisk aktivitet og energiforbruket i hvile kalles MET (metabolic equivalent). Hos voksne er 1 MET lik et oksygenopptak på 3,5 ml per kilo kroppsvekt per minutt $\left(3,5 \mathrm{ml} \mathrm{O}{ }_{2} \cdot \mathrm{kg}^{-1} \cdot \mathrm{min}^{-1}\right)$, noe som tilsvarer et kaloriforbruk på $1 \mathrm{kcal} \cdot \mathrm{kg}^{-1} \cdot \mathrm{time}^{-1}(8)$. All fysisk aktivitet resulterer i en økning i energiforbruket ut over hvilenivå, og energiforbruket utgjør et kontinuum der noen aktiviteter krever lite energi mens andre aktiviteter krever en mangedobling av energiforbruket (figur 1).

\section{Fysisk form}

Fysisk form er et sett av egenskaper som man har eller erverver seg, og som er relatert til evnen man har for å utføre fysisk aktivitet (2). Fysisk form kan deles opp i faktorer som aerob kapasitet (kondisjon), muskelstyrke, bevegelighet, hurtighet, koordinasjons- og reaksjonsevne, tekniske ferdigheter med mer.

Faktorene som utgjør fysisk form deles ofte inn i to grupper, hvor den ene hovedsakelig er relatert til idrettslige prestasjoner (prestasjonsrelatert form) og den andre til helse (helserelatert form) (2). Prestasjonsrelatert form henviser til de komponenter som er nødvendige for optimal idrettsprestasjon, mens helserelatert form defineres som en tilstand karakterisert av evnen til å utføre daglige aktiviteter med overskudd, og fysiologiske trekk og kvaliteter som er forbundet med lav risiko for utvikling av livsstilssykdommer og lidelser (figur 2).

\section{Trening}

Trening kan defineres som aktivitet som er planlagt, strukturert og repetitiv (det vil si gjentas regelmessig) i den hensikt å forbedre eller opprettholde en eller flere komponenter av den fysiske formen (2). Trening er altså en systematisk påvirkning av kroppen, og type trening vil variere avhengig av hvilke komponenter av fysisk form man ønsker å påvirke (for eksempel utholdenhetstrening, styrketrening, balansetrening) (9).

\section{Utholdenhet}

Utholdenhet er evnen til å arbeide med moderat til høy intensitet $\mathrm{i}$ forholdsvis lang tid, og er en kombinasjon

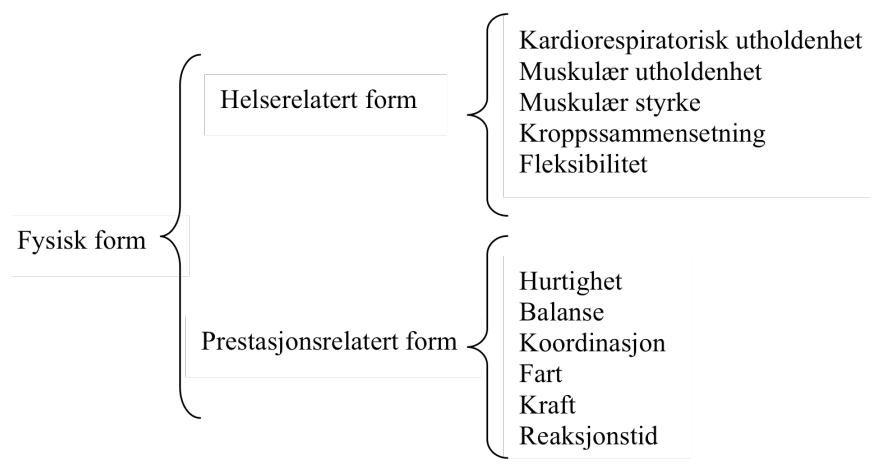

Figur 2. Oversikt over komponentene som utgjør fysisk form (2). 
av aerob og anaerob kapasitet (10). Aerob kapasitet står for organismens evne til å arbeide med relativt høy intensitet over lengre tid, mens anaerob kapasitet vil si organismens evne til å arbeide med svært høy intensitet $\mathrm{i}$ forholdsvis kort tid. I dagligtalen omtales utholdenhet ofte som kondisjon (10).

\section{2) Avklaringer basert både på eksisterende litteratur} og innspill fra relevante personer

Mosjon

Mosjon kan beskrives som lettere kroppsbevegelser som gir aktivitet til store deler av kroppen. Mosjon er en form for lettere fysisk aktivitet som ikke trenger å ha et bestemt mål, men kan gjerne utføres med tanke på å styrke helsen/den helserelaterte delen av fysisk form (9).

Trim

Kan likestilles med mosjon (9).

Idrett

I henhold til "Norges idrettsforbund og olympiske og paralympiske komités lov" forklares idrett som aktivitet som oppfyller følgende vilkår (11):

a) det er fysisk aktivitet av konkurranse-, treningsog/eller mosjonskarakter

b) aktiviteten er som konkurranseaktivitet målbar etter godkjent regelverk

c) aktiviteten tilfredsstiller de etiske normer idretten $\mathrm{i}$ Norge bygger sin aktivitet på

Idrett kan videre forklares som fysisk aktivitet av konkurranse-, trenings- og/eller mosjonskarakter hvor kroppsstillinger eller kroppsbevegelser er det sentrale element og hvor utøverens egen innsats er avgjørende for resultatet (9).

Sport

Sport kan forklares som en aktivitet bestemt av et sett av regler eller skikker/normer der man ofte konkurrerer. Sport refererer vanligvis til aktiviteter der utøverens fysiske dyktighet er hovedfaktoren som bestemmer utfallet (seier eller tap). Uttrykket blir imidlertid også brukt om idretter hvor redskap/hjelpemiddel er viktig for den totale idrettsprestasjon, som for eksempel ridesport, motorsport og luftsport.

\section{Friluftsliv}

Fysisk aktivitet og/eller opphold i natur med sikte på miljøforandring og naturopplevelse. Friluftsliv innebærer altså aktiviteter som i de fleste tilfeller kombinerer fysisk aktivitet og naturopplevelse, som for eksempel fotturer, skiturer, sopp- og bærplukking, jakt, fiske, klatring, padling og turorientering. I friluftsliv inngår også aktiviteter som innbærer kun opphold i natur, som bålbrenning, telting og soling m.m (12).

\section{Kroppsøving}

Kroppsøving er et skolefag som defineres ut fra den gjeldende læreplan. Sentralt i faget står bevegelseslek, allsidig idrett, dans og friluftsliv, der elevene ut fra egne forutsetninger skal kunne oppleve mestring og mestringsglede. Faget skal inspirere til bevegelse, kreativitet og selvstendighet (13).

\section{Fysisk aktivitet $i$ skolen}

All kroppslig bevegelse tilrettelagt slik at alle elever, uten hensyn til funksjonsnivå, kan oppleve glede, mestring, fellesskap og variasjon i skolehverdagen (14).

\section{3) Avklaringer utelukkende basert på innspill fra personer innen offentlig forvaltning og aktuelle fagmiljo i Norge}

\section{Hverdagsaktivitet}

Fysisk aktivitet som gjøres i forbindelse med daglige gjøremål, som å gå i trapper, åpne dører, gå eller sykle til og fra jobb, skole, barnehage, butikk, og fritidsaktiviteter, husarbeid, hagearbeid m.m.

\section{Lavterskelaktivitet}

Fysisk aktivitet som er lett tilgjengelig, det vil si at det ikke er nødvendig med bestemte ferdigheter, utstyr, forberedelser eller anlegg for å kunne utføre aktiviteten, og aktiviteten er lite kostnadskrevende.

\section{DISKUSJON}

Terminologien som brukes angående fysisk aktivitet og fysisk form både i vitenskapelig litteratur og i dagligtale varierer. Ulik forståelse av samme begrep kan virke forvirrende. Målet med dette arbeidet var derfor å komme frem til en generell avklaring som kan anvendes for hvert begrep, og det er derfor ikke forsøkt å presentere eller diskutere flere mulige forklaringer til hvert begrep.

Fysisk aktivitet er et vidt begrep, et såkalt paraplybegrep, og i dette begrepet inngår mange andre termer knyttet til fysisk utfoldelse, som for eksempel idrett, trening, sport, arbeid, mosjon, friluftsliv, lek og kroppsøving (6). Generelt kan man si at fysisk aktivitet er det å bevege seg og bruke kroppen. De fleste individer utøver en eller annen form for fysisk aktivitet i dagliglivet, men graden av fysisk aktivitet og energiforbruket det medfører varierer betydelig fra person til person. Intensiteten av aktiviteten deles ofte inn i lav, moderat og høy. Aktivitet med lav intensitet påvirker i liten grad pust og puls. Moderat intensitet fører til økt puls og får deg til å puste litt mer enn vanlig, og omtales gjerne som "snakketempo". Ved aktivitet med høy intensitet øker pulsen vesentlig og man blir så andpusten at det er vanskelig å snakke i hele setninger. Intensitetsnivået uttrykkes ofte som forholdet mellom energiforbruket under fysisk aktivitet og energiforbruket i hvile (MET). Et energiforbruk under 3 METs karakteriseres som lav intensitet, 3-6 METs som moderat intensitet og over 6 METs som høy intensitet. Dette er absolutte størrelser og må ikke forveksles med opplevd intensitet hos den som utfører aktiviteten. Eksempelvis vil det å gå i 4,8 $\mathrm{km} / \mathrm{t}$ kreve 4,5 MET (det vil si 4,5 ganger energiforbruket i hvile) mens løping på $15 \mathrm{~km} / \mathrm{t}$ krever $18 \mathrm{MET}$ (15). Hvordan intensiteten oppleves hos den som utfører aktiviteten vil forøvrig variere avhengig av den fysiske formen hos den enkelte. Jogging vil for eksempel kunne oppleves som moderat intensitet for en som er godt trent, mens en person som ikke er tilsvarende godt trent vil kunne oppleve samme aktivitet som meget 
anstrengende eller ikke gjennomførbar.

Mens fysisk aktivitet er en adferd er fysisk form et sett av egenskaper man har og som sier noe om evnen til å utføre fysisk aktivitet. I litteraturen brukes av og til kondisjon synonymt med fysisk form, men dette er kun én av komponentene som inngår i begrepet fysisk form.

Idrettsbegrepet er et vidt begrep som brukes med flere og omfattende betydninger. Forslaget som er presentert er i hovedsak basert på Norges idrettsforbunds definisjon, men per i dag finnes det likevel ingen entydig definisjon av idrettsbegrepet. For å unngå misforståelser kan det derfor ofte være nødvendig å forklare hva man mener når man bruker begrepet idrett.

Innen friluftsliv brukes flere begreper som friluftslivsaktivitet, friluftsaktivitet og aktivitet i friluft. Selv om begrepene tilsynelatende er like, er det noen nyanser knyttet til begrepene. Basert på innspill fra personer $\mathrm{i}$ fagmiljø og organisasjoner så kan friluftslivsaktivitet forklares som fysisk aktivitet $o g$ opphold i natur, mens friluftsaktivitet er fysisk aktivitet i natur. Friluftsliv kan derimot bety aktivitet og/eller opphold i natur, mens aktivitet $\mathrm{i}$ friluft er all aktivitet som foregår ute/i friluft. Det er viktig å understreke at definisjonen som er lagt til grunn for friluftsliv avviker noe fra definisjonen i Friluftslivsmeldingen (St. meld. nr 39 (2000-2001)) der det også stilles krav om at aktiviteten (friluftslivet) skal foregå i fritiden (12). I forhold til friluftsliv og fysisk aktivitet synes dette lite hensiktsmessig, da friluftsliv også blant annet benyttes i skolen.

\section{OPPSUMMERING}

Hensikten med arbeidet var å lage en oversikt over vanlig brukte begreper som er relatert til fysisk aktivitet og komme med forslag til hvordan disse begrepene kan og bør forklares uavhengig av fagfelt. Begrepsavklaringene er følgelig ment som en anbefaling i forhold til bruk og forståelse, men det er vanskelig å presentere noen form for fasit som omfatter alle nyanser av et begrep tilpasset alle formål. I en del tilfeller vil det derfor kunne være behov for ytterligere spesifisering av hva som legges $i$ et begrep, men arbeidsgruppen mener forslagene burde være dekkende $\mathrm{i}$ de fleste tilfeller. Målet er at begrepene med forklaringer skal kunne benyttes på tvers av ulike fagfelt, organisasjoner og studier slik at det blir en enhetlig forståelse av hva man mener når det benyttes et bestemt begrep.

\section{TAKKSIGELSER}

Takk til personer ved Norges idrettshøgskole, Direktoratet for naturforvaltning, Høgskolen i Telemark, Norsk institutt for naturforskning, Norges idrettsforbund, Statens vegvesen og Universitetet i Agder for nyttige innspill til flere av begrepsavklaringene, enten i forbindelse med utarbeidelse av arbeidsgruppens rapport eller $\mathrm{i}$ etterkant $\mathrm{i}$ forbindelse med høringsrunden for dokumentet.

\section{REFERANSER}

1. Departementene. Handlingsplan for fysisk aktivitet 2005-2009. Sammen for fysisk aktivitet. 1-120. 2004. Oslo.

2. Caspersen CJ, Powell KE, Christenson GM. Physical activity, exercise, and physical fitness: definitions and distinctions for health-related research. Public Health Rep 1985; 100: 126-131.

3. American College of Sports Medicine. ACSM's Guidelines for Exercise Testing and Prescription. USA: Lippincott Williams \& Wilkins, 2007.

4. Sosial- og helsedirektoratet. Fysisk aktivitet og helse. Kartlegging. 1, 1-49. 2001.

5. U.S.Department of Health and Human Services, Centers for Disease Control and Prevention. Physical Activity and Health: A report of the Surgeon General. 1996. Atlanta, GA, National Center for Chronic Disease Prevention and Health Promotion.

6. Sosial- og helsedirektoratet. Fysisk aktivitet og helse. Anbefalinger. 2. 2000. Oslo, Sosial- og helsedirektoratet.

7. Strømme SB, Høstmark AT. Fysisk aktivitet, overvekt og fedme. Tidsskr Nor Laegeforen 2000; 120: 35783582 .

8. American College of Sports Medicine. ACSM's Resource Manual for Guidelines for Exercise Testing and Prescription. USA: Williams \& Wilkins, 1998.

9. Olsen AM. Idrettens ordbok. Ord og uttrykk med forklaringer. Oslo: Akilles, 2005.

10. Gjerset A, Haugen K, Holmstad P. Treningslære. Oslo: Gyldendal Norsk Forlag, 2006.

11. NIF. Norges idrettsforbund og olympiske og paralympiske komités lov §1-2. NIF-loven. 2007.

12. Miljøverndepartementet.St.meld. nr. 39 (2000-2001). Friluftsliv - Ein veg til høgare livskvalitet. 2000.

13. Utdanningsdirektoratet. Læreplan i kroppsøving. http://www.udir.no/grep/Lareplan/?laereplanid=998762. 2010. 1-11-2010.

14. Utdanningsdirektoratet. Rett til fysisk aktivitet. 2009. Rundskriv Udir.

15. Anderssen SA, Strømme SB. Fysisk aktivitet og helse - anbefalinger. Tidsskr Nor Laegeforen 2001; 121: 2037-2041. 